University of Nebraska - Lincoln

DigitalCommons@University of Nebraska - Lincoln

Publications from USDA-ARS / UNL Faculty

U.S. Department of Agriculture: Agricultural

Research Service, Lincoln, Nebraska

2005

Insect Transmission of Plant Pathogens

Rodrigo P. P. Almeida

University of Hawaii at Manoa

Astri Wayadande

Oklahoma State University

Todd Shelly

USDA-APHIS

Follow this and additional works at: https://digitalcommons.unl.edu/usdaarsfacpub

Part of the Agricultural Science Commons

Almeida, Rodrigo P. P.; Wayadande, Astri; and Shelly, Todd, "Insect Transmission of Plant Pathogens" (2005). Publications from USDA-ARS / UNL Faculty. 377.

https://digitalcommons.unl.edu/usdaarsfacpub/377

This Article is brought to you for free and open access by the U.S. Department of Agriculture: Agricultural Research Service, Lincoln, Nebraska at DigitalCommons@University of Nebraska - Lincoln. It has been accepted for inclusion in Publications from USDA-ARS / UNL Faculty by an authorized administrator of DigitalCommons@University of Nebraska - Lincoln. 


\title{
Insect Transmission of Plant Pathogens
}

\author{
RODRIGO P. P. ALMEIDA, ${ }^{1}$ ASTRI WAYADANDE, ${ }^{2}$ AND TODD SHELLY ${ }^{3}$
}

MUCH OF BIOLOGICAL RESEARCH CONDUCTED TODAY is multidisciplinary, partly because of the availability of ever simpler to use molecular tools and the realization that ecological systems are complex and multitrophic. Although there is a general trend toward academic specialization and cooperation, some fields still require that scientists be aware of the "bigger picture." We consider that the study of insect-transmitted plant pathogens is one of those fields, where insect, pathogen, and plant are inseparably linked. In this triangle of interactions, researchers focus their interests on questions at the molecular and cellular to epidemiological levels. Throughout the years, plant vector entomologists have addressed a variety of important pest problems, often linking entomologists and plant pathologists for the development of improved and sustainable disease control strategies.

In this issue of the Annals of the Entomological Society of America, the Cc subsection (Arthropods in Relation to Plant Disease) of the Society honors two of its members, Lowell R. "Skip" Nault and Alexander H. "Sandy" Purcell. Skip and Sandy have been recognized as two of the ESA's preeminent plant vector entomologists. They were also partly responsible for training and motivating a new generation of scientists involved in vector-phytopathogen relationships. What made their contribution, recognized by tribute symposia at recent ESA meetings, so remarkable was their ability to study problems as multitrophic interactions, incorporating aspects of diverse research areas into their work as needed. Their contributions ranged from disease epidemiology and modeling to insect biology; from insect microbial ecology to bacterial genomics. The interests of Skip and Sandy merged in what might be labeled "ecology of insectborne plant diseases." In fact, they have written or coauthored several articles on the topic. To understand the ecology of such diseases, one must know how insects transmit plant disease agents and then incorporate that knowledge into vector ecology, crop management practices, and disease development and spread. This holistic approach to vector research, difficult to establish for various reasons, led to numerous academic and applied breakthroughs by both researchers.

Skip was an advisor, mentor, collaborator, and colleague to many who wandered through his door at one

\footnotetext{
${ }^{1}$ Department of Plant and Environmental Protection Sciences, University of Hawaii at Manoa, Honolulu, HI 96822.

${ }^{2}$ Department of Entomology and Plant Pathology, Oklahoma State University, Stillwater, OK 74078

${ }^{3}$ USDA-APHIS, 41-650 Ahiki Street, Waimanalo, HI 96795.
}

time or another during his tenure at The Ohio State University. Originally an aphidologist out of Sylvester's laboratory, Skip saw the light and began working with leafhopper-transmitted mollicutes and viruses. In the course of his 30-yr career at the Ohio Agricultural Research and Development Center in Wooster, $\mathrm{OH}$, Skip not only focused on vector-pathogen relationships but also ventured into new areas such as leafhopper communication, feeding behavior, and ecology, primarily through his many students and postdoctoral workers. In all, Skip trained 18 masters and doctoral students and published more than 120 refereed articles in various scientific journals. A great thinker, Skip liked to synthesize new ideas and hypotheses to test. Among his most lasting contributions are his early work with aphid alarm pheromones, Dalbulus-maize evolution concepts, and the synopses of plant virus modes of transmission.

During his $30 \mathrm{yr}$ as a faculty member at the University of California, Berkeley, Sandy incited interest of students, collaborators, and colleagues on various topics associated with vector-borne plant diseases. The never-ending interest he had toward all areas of science and his willingness to discuss academic questions and ideas have motivated students and colleagues worldwide. Sandy headed research that identified the etiological agent of Pierce's disease of grape and other plant diseases, the bacterium Xylella fastidiosa; studied its vector transmission characteristics; and improved our understanding on the ecology and epidemiology of this pathogen. Plant pathogenic mollicutes (phytoplasmas and spiroplasmas) and their interactions with their leafhopper hosts also were continuous components of his research. Another line of Sandy's research was insect symbiosis, primarily facultative symbionts of the pea aphid, Acyrthosiphon pisum (Harris). The wide range of tools used by Sandy to address unique ecological questions also was a hallmark of his contributions.

Members of the $\mathrm{Cc}$ subsection have submitted manuscripts representing many, but by no means all, research areas worked on by these two researchers. The manuscripts also demonstrate the breadth of plant vector entomology and its importance in linking entomology and plant pathology in search of better ways to control insect-borne plant diseases.

Finally, we are grateful to all those who served as reviewers for these manuscripts. Their thoughtful comments were essential for improvements in the final presentation. 